\title{
ANTIOXIDANT AND TOXICITY ACTIVITY IN VITRO OF TWELVE SAFROLE DERIVATIVES
}

\author{
ALEJANDRO MADRID ${ }^{1, *}$, LUIS ESPINOZA ${ }^{1}$, CATALINA PAVÉZ $Z^{2}$, HÉCTOR CARRASCO $^{3}$ AND \\ MARÍA ELIANA HIDALGO ${ }^{2} *$
}

\author{
${ }^{\perp}$ Departamento de Química, Universidad Técnica Federico Santa María, Av. España $N^{\circ} 1680$, Valparaíso, Chile. \\ ${ }^{2}$ Facultad de Ciencias, Universidad de Valparaíso, Gran Bretaña 1111, Valparaíso, Chile. \\ ${ }^{3}$ Facultad de Ciencias Exactas., Universidad Andrés Bello, Quillota 910, Viña del Mar, Chile.
}

\begin{abstract}
The aim of this study was to determine the influence of substituents in aromatic ring and the side chain of safrole on the antioxidant capacity and toxicity of twelve synthetic derivatives of safrole (S1-S12). Each compound was analyzed by two antioxidant methods: DPPH and bleaching of $\beta$-carotene (DBC). Among the derivates of safrol assayed, S5, S6, S9, S10 and S11 showed the strongest antioxidant capacity: DPPH method, first order specific rate constant $(0.0152,0.0211$, $0.0432,0.0317$ and 0.0072$)$ and DBC $(22.41 \pm 0.13 \%, 10.71+0.05 \%, 9.12 \pm 0.89 \%, 30.97 \pm 0.92 \%$ and $19.08 \pm 0.31 \%)$, respectively. The toxicity of the active compounds was evaluated by means of two techniques, Artemia salina, $\mathrm{LD}_{50}(4466 \pm 1057 \mathrm{ppm}, 630 \pm 108 \mathrm{ppm}, 1513 \pm 797 \mathrm{ppm}, 1585 \pm 317 \mathrm{ppm}, 1259 \pm 242$ $\mathrm{ppm})$ and red cells, Haemolysis $(1.58 \pm 0.98 \%, 4.02 \pm 2.03 \%, 8.42 \pm 1.38 \%, 2.59 \pm 2.31 \%, 2.92 \pm 0.52 \%)$, to provide preliminary information that can be used as a basis for further studies to contribute to the search for new antioxidants.
\end{abstract}

Key words: Safrole derivatives; Antioxidant Capacity; Phenylpropanoid; DPPH; b-Carotene.

\section{INTRODUCTION}

Safrole (Figure 1) is a phenylpropanoid widely distributed in the plant kingdom main component of sassafras oil, obtained from Sassafras sp. A genus of plants consisting of two species of deciduous trees of the family Lauraceae, native to Eastern North America and East Asia. Safrole also is present in oils from the species Laurelia sempervirens, the "Chilean Laurel" a tree native to Chile localized from VI to X region ${ }^{1}$. The oil obtained from the Laurel, is used as flavoring in foods and cosmetics, however, terminated its use due to its toxicity (hepatotoxicity and carcinogenicity) , $^{2,3}$, although it is still used as flavorings in technical products such as insecticides and disinfectants ${ }^{4}$. The Adverse effects of safrole greatly depend on the formation of safroleDNA adducts 5 . These adducts were formed following the hepatic cytochrome P450 biotransformation of safrole to 1'-hydroxy-safrole. ${ }^{6}$. There has been growing interest in the synthesis of safrole derivates for bioorganic chemistry because these compounds are much less toxic compared to safrole. Several of these compounds, have been present a potent cytotoxic activity against two breast cancer cell lines, MCF-7, MDA-MB231 $1^{7,8}$, including safrole oxide and 1-ethoxy-3-(3,4-methylenedioxyphenyl)-2-propanol (EOD), have been found to inhibit angiogenesis ${ }^{9}$ and to arrest the growth and induce death of human tumor cells in vitro ${ }^{10}$. Molecular mechanisms of cancer cell death are associated with structural characteristics of safrole derivates ${ }^{11}$. Transformation of side chain of safrole is a crucial step in achieving cancer prevention through induction of apoptosis and decreased proliferation of pre-malignant cells $\mathrm{s}^{11}$.

Such structural changes are directly related to free radical scavenging activity and the cytotoxic activity ${ }^{12}$. On the other hand, In vitro studies and experiments in animal models suggest that the pharmacological activities such as cytoprotective, antitumoral promoting, antiinflammatory, antipyretic and antiplatelet activities have been associated with the ability of fenolic compounds to scavenge highly reactive free radicals ${ }^{13,14}$.

In this sense, there is evidence that synthetic antioxidants, some of which possess hydroxyl and nitro groups in their structures, inhibit LDL oxidation and cardioprotective effects ${ }^{15-18}$; for this reason the antioxidant capacity of safrole derivatives with phenolic structure and nitro substituent's, might give us excellent a priori information about this property when not yet studied.

In this study, we evaluated the influence of substituents in aromatic ring and the side chain of safrole: 4-Allyl-5-nitro-1,2-methylenedioxy benzene S1, 3-(3', 4'-methylenedioxy-6'-nitro) phenylpropan-1ol S2, 3-(3', 4'-methylenedioxy-6-nitro) phenylpropyl acetate S3, 3-(3',4'-methylenedioxy) phenylpropan-1-ol S4, 4-allyl-5-nitrobenzene-1,2diol S5, 4-allyl-5-nitro-1, 2-phenyl diacetate S6, 4-[3-(acetyloxy)propyl]-1,2phenyl diacetate $\mathbf{S 7}$, 4-allyl-1,2-phenyl diacetate $\mathbf{S 8}$, 4-[3-(acetyloxy) propyl] 5-nitro-1,2-phenyl diacetate S9, 4-(3-hydroxypropyl)-5-nitrobenzene-1,2-diol S10, 4-allylbenzene-1,2-diol S11, 4-propyl-1,2-phenyl diacetate) S12 on biological properties: antioxidant capacity and toxicity, in order to explain the possibility of such compounds to act either as antioxidant agents.

\section{EXPERIMENTAL SECTION}

\section{General}

Safrol, reagents and solvents used in the present synthesis, antioxidant and toxicity tests were purchased from Sigma-Aldrich (St. Louis, MO). Shrimp eggs were purchased from an aquarium shop.

Synthesis of safrole derivatives

Safrole derivatives S1-S12 (Figure 1) were synthesized and characterized by standard methods 7,8 .

\section{Antioxidant capacity}

\section{DPPH assay}

DPPH was dissolved in $\mathrm{MeOH}$ to obtain a concentration of $100 \mu \mathrm{M}$. Serial dilutions were carried out with methanol of compounds (S1-S12) to obtain concentrations of: $25,50,75,100 \mu \mathrm{M}$. Diluted solutions $(0.1 \mathrm{~mL}$ each) were mixed with DPPH $(100 \mu \mathrm{M})$. The UV absorbance was recorded at $517 \mathrm{~nm}$ each 5 minutes during 30 minutes. The experiment was performed in triplicate and the average absorption was noted for each concentration. The same procedure was followed for the positive control Trolox ${ }^{\circledR 19}$.

\section{Autooxidation of b-Carotene}

A diluted, oxygenated emulsion was prepared by the following procedure. A sample of crystalline b-Carotene $(2 \mathrm{mg})$ was dissolved in $\mathrm{CHCl}_{3}(10 \mathrm{~mL})$ and an aliquot of this solution $(1 \mathrm{~mL})$ and was added to purified linoleic acid $(20$ $\mathrm{mg}$ ) and Tween 40 emulsifier $(200 \mathrm{mg})$. After removal of $\mathrm{CHCl}_{3}$ in a rotatory evaporator, oxygenated distilled $\mathrm{H}_{2} \mathrm{O}(50 \mathrm{~mL})$ was added with vigorous stirring. An aliquot $(5 \mathrm{~mL})$ was pipetted into a spectrometer tube containing EtOH $(0.2$ $\mathrm{mL}$ ) and the desired amount of antioxidant. The tubes were stoppered and placed in a $\mathrm{H}_{2} \mathrm{O}$ bath at $50{ }^{\circ} \mathrm{C}$. Readings of absorptions at $470 \mathrm{~nm}$ were taken at regular intervals ${ }^{20}$. The Antioxidant Activity (AA) was evaluated from the equation:

$A A=100\left[1-\left(A_{0}-A_{t}\right) /\left(A_{0}^{0}-A^{0}\right)\right]$

where $A_{0}$ is the A measured at the beginning of the incubation and $A_{t}$ and $\mathrm{A}_{\mathrm{t}}^{\circ}$ are the $\mathrm{A}$ measured in the presence and absence, respectively, of the additive after incubation.

\section{Toxicity analysis}

Toxicity test: Eggs from Artemia saline

Artemia saline (Class: Crustacea, Subclass: Branchiopode; Super order: Anostracea, Family: Artemidae, Genus: Artemia) cysts were incubated in filtered (micropore $0.22 \mu \mathrm{m}$ ) sea water and oxygenated for $45 \mathrm{~min}$ at $30{ }^{\circ} \mathrm{C}$ in a thermo regulated bath and adjusted to $\mathrm{pH} 8$ with $\mathrm{NaOH} 0.1 \mathrm{M}$. After $24 \mathrm{~h}$, the eclosionated nauplius (first stage of Artemia saline) are in an appropriate condition for toxicity tests conditions. A solution of each concentration $(1 \mathrm{~mL})$ 
was transferred into clean sterile universal vials with pipette, and aerated seawater $(9 \mathrm{~mL})$ was added. About 10 nauplius were transferred into each vial with pipette. A check count was performed and the number alive after $24 \mathrm{~h}$ was noted. $\mathrm{LD}_{50}$ values were determined using the Probit analysis method ${ }^{21}$.<smiles>C=CCc1cc2c(cc1[N+](=O)[O-])OCO2</smiles><smiles>OCCCc1cc2c(cc1[As])OCO2</smiles><smiles>C=CCc1ccc(O)c(O)c1</smiles>
s 7<smiles>O=[N+]([O-])c1c(CCCO)cc(O)c(O)c1[S-]</smiles><smiles>C=CCc1ccc2c(c1)OCO2</smiles>

Safrole<smiles>O=[N+]([O-])c1cc2c(cc1CCCO)OCO2</smiles><smiles>C=CCc1cc(O)c(O)c(S(=O)(=O)[O-])c1[N+](=O)[O-]</smiles>

s 5<smiles>C=CCc1ccc(OC(C)=O)c(OC(C)=O)c1</smiles>

S 8<smiles>CC(=O)OCCCc1cc(S)c(OC(C)=O)c(OC(C)=O)c1</smiles><smiles>CC(=O)OCCCc1cc2c(cc1[N+](=O)[O-])OCO2</smiles><smiles>C=CCc1cc(OC(C)=O)c([N+](=O)[O-])c([S+](=O)[O-])c1</smiles><smiles>CC(=O)OCCCc1cc(OC(C)=O)c([N+](=O)[O-])cc1[N+](=O)[O-]</smiles><smiles>CCCc1cc([AsH2])c(OC(C)=O)c(OC(C)=O)c1</smiles>

Figure 1. Structures of safrole and derivatives.

\section{Toxicity in red cell model}

Red blood cells of healthy adult donors (University students) were used. Shortly after collection, the heparinised blood was centrifuged at $2.000 \mathrm{~g}$ and both the plasma and buffy coat discarded. The remaining red cells were washed three times with an isotonic solution $(0.15 \mathrm{M} \mathrm{NaCl}$ on $0.01 \mathrm{M}$ sodium phosphate (PBS), $\mathrm{pH} 7.4$ ). The red cells were resuspended to approximately $2 \% \mathrm{v} / \mathrm{v}$, kept at $6^{\circ} \mathrm{C}$ and used in the next $72 \mathrm{~h}$. The percentage of haemolysis was determined immediately after irradiation by measuring the haemoglobin liberated in the medium from solutions containing $0.4 \%$ red cells $^{22}$. Measurements were carried out at 540,560,577, 630 and $700 \mathrm{~nm}$, and the concentrations were evaluated according to the Winterbourn equation ${ }^{23}$.

\section{Statistic analysis}

Results are presented as mean \pm standard error; statistical analysis of experimental results of DPPH and DBC were analyzed by a nonparametric test (Kruskal-Wallis) with a confidence level of $95 \%$ using the program STATISTICA 7.0. For $\mathrm{LC}_{50}$ values probit analysis was used with the software MINITAB 15, with a confidence level of $95 \%$. Significant difference was statistically considered at the level of $P<.001$.

\section{RESULTS AND DISCUSSION}

The principle of antioxidant activity is based on the availability of electrons to neutralize any free radical $\mathrm{s}^{24}$. In addition, antioxidant activity is related to the number and the nature of the hydroxylation pattern on the aromatic ring. It is generally assumed that the ability to act as hydrogen donor and the inhibition of oxidation are enhanced by the increase in the number of hydroxyl groups in the phenol ring ${ }^{25}$. Apiol, chavicol, eugenol and derivates, like 5-Allyl-3nitrobenzene-1,2-diol, have greatest capacity as free radical scavengers, due to the presence of one or more phenolic groups in the aromatic ring ${ }^{26-28}$, is reasonable to assume then, the molecules with similar chemical structures present a similar antioxidant activity. In this study, safrole derivatives were screened for their possible antioxidant activity by DPPH radical scavenging and $\beta$-carotene. These methods have been used to evaluate the antioxidant activity of compounds because of the simple, rapid, sensitive, and reproducible procedures $^{29}$.

The effect of antioxidant on DPPH radical scavenging was thought to be due to their hydrogen donating ability. It has been reported that free radical scavenging activity is greatly influenced by the free hydroxyl groups of the samples $^{30}$.

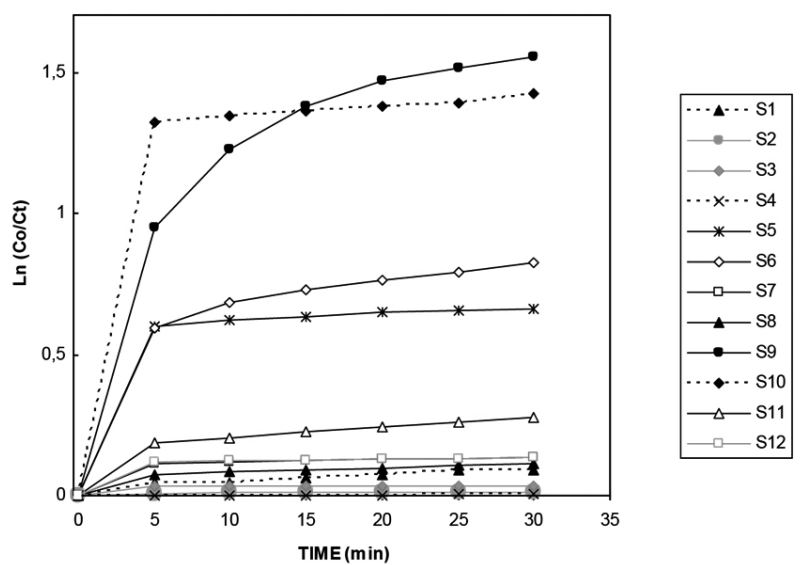

Figure 2. Consumption rate constant $(\mathrm{k})$ determination from radical absorption $(75 \mu \mathrm{M})$ at $517 \mathrm{~nm}$ (DPPH method). 
Figure 2, the rate of decay of the absorbance of the radical (k) or the slope of each line, it was determined using a first order kinetics, by linear regression ${ }^{19}$ (see Table 1).

Table 1. First order specific rate constants for safrole derivatives.

\begin{tabular}{|c|c|c|}
\hline Compound & Concentration $(\boldsymbol{\mu M})$ & $\mathbf{k}$ \\
\hline S1 & 75 & $\mathbf{0 . 0 0 2 4}$ \\
\hline S2 & 75 & $\mathbf{0 . 0 0 0 3}$ \\
\hline S3 & 75 & $\mathbf{0 . 0 0 0 7}$ \\
\hline S4 & 75 & $\mathbf{0 . 0 0 0 1}$ \\
\hline S5 & 75 & $\mathbf{0 . 0 1 5 2}$ \\
\hline S6 & 75 & $\mathbf{0 . 0 2 1 1}$ \\
\hline S7 & 75 & $\mathbf{0 . 0 0 3 3}$ \\
\hline S8 & 75 & $\mathbf{0 . 0 0 2 9}$ \\
\hline S9 & 75 & $\mathbf{0 . 0 4 3 2}$ \\
\hline S10 & 75 & $\mathbf{0 . 0 3 1 7}$ \\
\hline S11 & 75 & $\mathbf{0 . 0 0 7 2}$ \\
\hline S12 & 75 & $\mathbf{0 . 0 0 3 1}$ \\
\hline TROLOX & 75 & $\mathbf{0 . 0 5 3 8}$ \\
\hline
\end{tabular}

Results of DPPH method (Table 1 and Figure 2) demonstrated that derivatives S5 (4-allyl-5-nitrobenzene-1, 2-diol), S6 (4-allyl-5-nitro-1, 2-phenyl diacetate), S9 (4-[3-(acetyloxy) propyl]-5-nitro-1, 2-phenyl diacetate), S10 (4-(3-hydroxypropyl)-5-nitrobenzene-1, 2-diol), decreased significantly ( $p=$ $0.000)$ the absorbance values in accordance with a greater antioxidant capacity compared to other derivatives of safrole, the higher the value of $k$, the higher the antioxidant activity. Compounds $\mathbf{S 5}$ and $\mathbf{S 1 0}$ have hydroxyl groups and nitro, located at aromatic ring moiety, which would be responsible for its antioxidant properties. The phenolic groups in the aromatic ring allow the formation of a phenolic radical which is stabilized by a resonance with the aromatic system. Both compounds are those with the greatest number of resonant structures, compared to other derivatives, generating a higher stability to the phenolic radical. Compounds $\mathbf{S 6}$ and $\mathbf{S 9}$ have nitro groups and acetate which are substituents with inductive effect (electron-withdrawing groups) that, in the case of S6, induce the formation of an allyl radical stabilized by resonance. The possibility of generating the allyl radical in $\mathbf{S 9}$ is not feasible since it has no allylic structures in the side chain and the activity ought to be governed by the presence of the $\mathrm{NO}_{2}$ group who increases with two resonance structures and this molecule has a resonant structure unless than $\mathbf{S 6}$, corresponding to that provided by the allyl radical. On the other hand, similar antioxidant activity has also been reported for the phenylpropanoids acetylated, like 2-Methoxy-4-[1propenylphenyl]acetate and 1'-Acetoxychavicol acetate ${ }^{27,31}$.

$\beta$-Carotene bleaching assay was evaluated by measuring the inhibition of conjugated diene hydroperoxides starting from linoleic acid oxidation. Compounds containing hydrogen atoms in the allylic and/or benzylic positions give better activity in this test because of relatively easy abstraction of hydrogen atom from these functional groups by peroxy radicals formed in the test circumstances ${ }^{32}$. The results of DBC method (Table 2) shows coincidence with the antioxidant capacity of compounds S5, S6, S9, S10 and S11. The effectiveness of S10 (30.97 $\pm 0.92 \%)$ was higher than S9 $(9.12 \pm 0.89 \%)$, which were lower compared to control.

\section{Toxicity analysis}

The brine shrimp lethality bioassay is an efficient, rapid and inexpensive test that requires only a relatively small amount of sample. This bioassay has a good correlation with antioxidant activity, cytotoxic activity in some human solid tumors and with pesticidal activity, and has led to the discovery of the annonaceous acetogenins as a new class of natural pesticides and active antitumoral agents ${ }^{33}$. The results obtained in the bioassay with Artemia salina, indicate that S6 is more toxic in comparison with the others $(\mathbf{S 5}, \mathbf{S 9}, \mathbf{S 1 0}, \mathbf{S 1 1})$, because needs a lower concentration to achieve $50 \%$ mortality (Table 3 ).
Table 2. Antioxidant capacities (AA) of safrole derivatives evaluated from protection of $b$-Carotene.

\begin{tabular}{|c|c|c|}
\hline Compound & Concentration $(\boldsymbol{\mu M})$ & AA (\%) \\
\hline S1 & 75 & $2.58 \pm 0.02$ \\
\hline S2 & 75 & $2.08 \pm 0.35$ \\
\hline S3 & 75 & $6.43 \pm 0.40$ \\
\hline S4 & 75 & $1.25 \pm 0.23$ \\
\hline S5 & 75 & $22.41 \pm 0.13$ \\
\hline S6 & 75 & $10.71 \pm 0.05$ \\
\hline S7 & 75 & $5.17 \pm 0.06$ \\
\hline S8 & 75 & $1.36 \pm 0.12$ \\
\hline S9 & 75 & $9.12 \pm 0.89$ \\
\hline S10 & 75 & $30.97 \pm 0.92$ \\
\hline S11 & 75 & $19.08 \pm 0.31$ \\
\hline S12 & 75 & $4.08 \pm 0.45$ \\
\hline TROLOX & 100 & $89.72 \pm 0.47$ \\
\hline
\end{tabular}

Table 3. $\mathrm{LD}_{50}(\mathrm{ppm})$ values for safrole derivatives.

\begin{tabular}{|c|c|c|c|}
\hline Compound & LD $_{\mathbf{5 0}}$ & $\mathbf{X}^{\mathbf{2}}$ & Confidence Limit \\
\hline S5 & 4466 & 0.98 & \pm 1057 \\
\hline S6 & 630 & 0.54 & \pm 108 \\
\hline S9 & 1513 & 0.41 & \pm 797 \\
\hline S10 & 1585 & 0.39 & \pm 317 \\
\hline S11 & 1259 & 0.97 & \pm 242 \\
\hline
\end{tabular}

The results of toxicity in red blood cell model, provided information on the damage caused by derivatives of safrole in the erythrocyte plasma membrane. The values obtained, indicate that compounds S5, S6 and S9, present negligible hemolytic capacity $(0.7,0.33,0.82 \%$ respectively) at 10 $\mathrm{ppm}$, attributable to mechanical damage. At $100 \mathrm{ppm}, \mathbf{S 6}$ and $\mathbf{S 1 0}$ cause higher hemolysis ( 8.42 and $4.02 \%$ respectively) than the compounds $\mathbf{S 5}$ and $\mathbf{S 9}$ (Table 4). These differences could be attributed to the presence of acetyl group. All the compounds exhibited hemolytic activity (minor than $10 \%$ ) for this reason; these compounds can be considered non-toxic.

Table 4. Haemolysis percentage for safrole derivatives.

\begin{tabular}{|c|c|c|c|c|c|}
\hline \multicolumn{7}{|c|}{ \% Haemolysis } \\
\hline $\begin{array}{c}\text { Concentration } \\
\text { (ppm) }\end{array}$ & S5 & S6 & S9 & S10 & S11 \\
\hline \multirow{2}{*}{10} & $\begin{array}{c}0.7 \pm \\
1.32\end{array}$ & $\begin{array}{c}0.33 \pm \\
1.01\end{array}$ & $\begin{array}{c}2.26 \pm \\
0.82\end{array}$ & $\begin{array}{c}0.89 \pm \\
1.67\end{array}$ & $\begin{array}{c}0.48 \pm \\
0.98\end{array}$ \\
\hline 100 & $\begin{array}{c}1.58 \pm \\
0.98\end{array}$ & $\begin{array}{c}4.02 \pm \\
2.03\end{array}$ & $\begin{array}{c}8.42 \pm \\
1.38\end{array}$ & $\begin{array}{c}2.59 \pm \\
2.31\end{array}$ & $\begin{array}{c}2.92 \pm \\
0.52\end{array}$ \\
\hline
\end{tabular}

Keeping in mind these factors, as well as the experimental methodology; it could be thought that the low percentage of haemolysis was correlated with the cytotoxic and selective effects on the breast cancer cells lines of these compounds ${ }^{8}$. The hemolytic capacity of these compounds also exhibited the similar trend of effects on a normal cell line DHF. This would explain that the anticancer and hemolytic activities were correlated with of the molecules hydrophobicity as well, although within different magnitude, that is, the highest hydrophobicity of safrol derivates, the stronger haemolysis against human red blood cells $\mathrm{s}^{34}$. For this compounds specificity between cancer cells and normal cells, it is generally accepted that the specificity depends on the compositional difference between the cell membranes ${ }^{35}$. 


\section{CONCLUSION}

In both methods to determine antioxidant activity, exists a concordance of the results, which showed that the compounds S5, S6, S9 and S10, have the greatest capacity free radical scavengers, due to the presence of one or more phenolic and nitro groups in the aromatic ring $\mathbf{S 6}$ caused less hemolysis on red blood cell, at a concentration of $10 \mathrm{ppm}$ S10 caused $0 \%$ mortality of Artemia salina at both concentrations used in toxicity testing. There are numerous examples of successful use of antioxidants to ameliorate pathologic sequelae of oxidative stress, in this sense $\mathbf{S 1 0}$ may be considered in the future as preservative agent and may also be treated as antioxidant in a broader (biomedical) sense.

\section{ACKNOWLEDGMENTS}

The authors thank DGIP of Universidad Técnica Federico Santa María for financing (Project DGIP N ${ }^{\circ}$ 13.11.36, PAC 2010-2014 for A. M.) and Universidad Andrés Bello (grant DI-24-10/R), supporting this research.

\section{REFERENCES}

1. M. Montes, L. Valenzuela \& T. Wilkomirsky. Anales de la Real Academia de Farmacia, 56, 49, (1990)

2. E. C. Miller, A. B. Sxanson, D. H. Phillips, T. L. Fletcher and A. Liem. Cancer Res., 43, 1124, (1981)

3. M. Jin, A. Kijima, Y. Suzuki, D. Hibi, T. Inoue, Y. Ishii, T. Nohmi, A. Nishikawa, K. Ogawa, T. Umemura. Toxicol., 290, 312, (2011)

4. P. R. R. Costa. Quimica Nova, 23, 357, (2000)

5. T. Y. LIU, C. C. CHEN, C. L. CHEN and C. W. CHI. Food Chem. Toxicol., 37, 697, (1999)

6. J. A. Miller and E. C. Miller Br. J. Cancer, 48, 1, (1983).

7. L. Espinoza, A. Madrid, L. Taborga, J. Villena, M. Cuellar, H. Carrasco. J. Chil. Chem. Soc., 55, 219, (2010)

8. A. Madrid, L. Espinoza, I. Montenegro, J. Villena, H. Carrasco. Molecules, 16, 4632, (2011)

9. B. Zhao, A. Du, J. Miao, K. Zhao, C. Q. Du. Vasc. Pharmacol., 40, 183, (2003)

10 A. Y. Du, B. Zhao, D. Yin, S. Zhang and J. Miao. Bioorg. Med. Chem., 13, 4176, (2005)

11 L. Y. Wang, X. H. Wang, J. L. Tan, S. Xia, H. Z. Sun, J. W. Shi, M. D. Jiang, L. Fang, H. Zuo, G. Dupati, K. Jang, and D. S. Shin. Bull. Korean Chem. Soc., 33, 3571, (2012)

12. M. Esteves, C. Siquet, A. Gaspar, V. Rio, J. Sousa, S. Reis, M. Marques, F. Borges. Archiv der Pharmazie - Chemistry in Life Sciences, 341, 164, (2008)

13. S. Martínez, Y. Madrero, M. Elorriaga, M. A. Noguera, B. Cassels, E. Sobarzo, P. D'Ocon, M. D. Ivorra. Life Sci., 64, 1205, (1999)

14. M. R. Saha, S. M. R. Hasan, R. Akter, M. M. Hossain, M. S. Alam, M. A. Alam, and M. E. H. Mazumder. Bangl. J. Vet. Med., 6, 197, (2008)
15. K. Kondo, R. Hirano, A. Matsumoto, O. Igarashi, H. Itakura, Lancet., 348, 1514, (1996)

16. H. Speisky, B. K. Cassels, E. A. Lissi, L. A. Videla, Biochem. Pharmacol. 41, 1575, (1991)

17. A. Mazur, D. Bayle, C. Lab, E. Rock, Y. Rayssiguier. Atherosclerosis, 145, 421, (1999).

18. Y. Nagasako-Akazome, T. Kanda, M. Ikeda and H. Shimasaki. J. Oleo Sci., 54, 143, (2005)

19. D. O. Kim, K. W. Lee, H. J. Lee, Y. C. Lee. J. Agric. Food Chem., 50, $3713,(2002)$

20. M. Lee, Z. Y. Yang, H. Li, L. Chen, Y. Sun, S. Gobbo, D. A. Balentine, C. S. Yang. Cancer Epidemiol. Biomarkers Prev., 4, 333, (1995)

21. J. L. McLaughlim, J. C. Chang, D. Smith. Simple bench-top bioassay (brine shrimp and potato discs) for the discovery of plant antitumor compounds. In Kinghorn AD, Balandrin MF (Eds.), Medicinal Agents from Plants, ACS Symposium Series 534, Washington, DC, USA, 1991; pp. 112-137.

22. L. Tobella,S. Cabrera, R. Moreno. Rev. Med. Chile, 122, 861, (1994)

23. C. C. Winterbourn. Oxidative reactions of hemoglobin. In L. Packer \& A.N. Galzer (Eds.) Methods in Enzimology Academic Press, San Diego, California, USA, 1990; pp. 265-272.

24. E. Denisov, I. Afanas'ev. Oxidation and Antioxidants in Organic Chemistry and Biology. CBC Taylor \& Francis Group, Boca Raton, London, New York, Singapore, 2005; p. 510.

25. V. Roginsky, E. A. Lissi. Food Chem., 92, 235-254, (2005)

26. M. E. Hidalgo, C. De la Rosa, H. Carrasco, W. Cardona, C. Gallardo, L. Espinoza. Quim. Nova, 32, 1467-1470, (2009)

27. M. O. GATA, M. H. OSHI, S. U. RANO, T. E. NDO. Chem. Pharm. Bull. 48, 1467-1469, (2000)

28. N. Mahae, S. Chaiseri. Kasetsart J. (Nat. Sci.), 43, 358-369, (2009)

29. R. Amarowicz, R. B. Pegg, P. Rahimi-Moghaddam, B. Barl, J. A. Weil. Food Chem. 84, 551-562, (2004)

30. A. H. Ebrahimabadi, E. H. Ebrahimabadi, Z. Djafari-Bidgoli, F. J. Kashi, A. Mazoochi, H. Batooli. Food Chem., 119, 452-458, (2010)

31. K. Kubota, Y. Ueda, M. Yasuda, A. Masuda. Occurrence and antioxidative activity of 1'-acetoxychavicol acetate and its related compounds in the rhizomes of Alpinia galanga during cooking. In A. M. Spanier, F. Shahidi, T. H. Parliment, and C. T. Ho (eds.). Food Flavors and Chemistry: Advances of the New Millennium. Royal Society of Chemistry. Cambridge, UK, 2001; pp. 601-607.

32. L. M. Cheung, P. C. K. Cheung, V. E. C. Ooi. Food Chem., 81, 249-255, (2003)

33. J. L. McLaughlin, L. L. Rogers, J. E. Anderson. Drug Inf. J. 32, 513-524, (1998)

34. Y. Huang, X. Wang, H. Wang, Y. Liu, Y. Chen. Mol. Cancer Ther., 10, 416, (2011)

35. D.W. Hoskin, A. Ramamoorthy. Biochim. Biophys. Acta, 1778, 357, (2008) 